First Peoples Child \& Family Review

An Interdisciplinary Journal Honouring the Voices, Perspectives, and Knowledges of

First Peoples through Research, Critical Analyses, Stories, Standpoints and Media

Reviews

\title{
Tenoch's Gender Journey: Case Study of a 13-year-old Mexican Refugee with Aboriginal Ancestry - Naming the Gaps Between Theory and Practice
}

\section{Silvia Tenenbaum}

Volume 7, Number 2, 2013

URI: https://id.erudit.org/iderudit/1068838ar

DOI: https://doi.org/10.7202/1068838ar

See table of contents

Publisher(s)

First Nations Child and Family Caring Society of Canada

\section{ISSN}

1708-489X (print)

2293-6610 (digital)

Explore this journal

Cite this article

Tenenbaum, S. (2013). Tenoch's Gender Journey: Case Study of a 13-year-old Mexican Refugee with Aboriginal Ancestry - Naming the Gaps Between Theory and Practice. First Peoples Child \& Family Review, 7(2), 27-33.

https://doi.org/10.7202/1068838ar

\section{Article abstract}

This paper explores the issues and technique that were used with a group of non-conforming youth to prepare them for successful entrance into university. It will produce and affirmation of the inner wisdom of non-traditional students as a mirror of learning for traditional teachers, to provide an example of dialogic learning through a de-colonizing lens. Then it will present the results of six years of group support and counselling to prove that denouncing the gaps in institutionalized systemic barriers to sexual minorities, coupled with persistent clincal, advocacy, and community activism, is effective in breaking the cycles of magrinalization of fervent, creative, and resilient youth once termed "at risk". Immigrant latino youth in general and the case study of Tenoch in particular shows that a direct application of present clinical practices are not enough to provide long-term healing and decolonizing attitudes to survive the academic needs of a border-gender communities. Regularm on-going therapy focused on anti-oppressive pracitces coupled with Aboriginal healing techniques has proved to be a valid, reliable, and consistent method to increase this vulnerable population's well-being without further marginalization. A practitioner might conclude that mixed model is more affirmative of individual process of personhood while still connected to one's roots and communities of origin. The implication of practice is that a clinical needs to also engage in advocacy, support, and profound transformations in order to unmask both inner and outer colonized mind traps.
This document is protected by copyright law. Use of the services of Érudit (including reproduction) is subject to its terms and conditions, which can be viewed online.

https://apropos.erudit.org/en/users/policy-on-use/ 


\title{
First Peoples Child \& Family Review
}

An Interdisciplinary Journal Honoring the Voices, Perspectives and Knowledges of First Peoples

through Research, Critical Analyses, Stories, Standpoints and Media Reviews

\section{Tenoch's Gender Journey: Case Study of a 13-year-old Mexican Refugee with Aboriginal Ancestry - Naming the Gaps Between Theory and Practice}

\author{
Silvia Tenenbaum \\ BA, MA, PhD (BD), BEd, MEd, EdD Candidate in the Applied Psychology \& Human Development Department (OISE), \\ Counselling Psychology Program at the University of Toronto
}

\begin{abstract}
This paper explores the issues and technique that were used with a group of non-conforming youth to prepare them for successful entrance into university. It will produce an affirmation of the inner wisdom of non-traditional students as a mirror of learning for traditional teachers, to provide an example of dialogic learning through a de-colonizing lens. Then it will present the results of six years of group support and counselling to prove that denouncing the gaps in institutionalized systemic barriers to sexual minorities, coupled with persistent clinical, advocacy, and community activism, is effective in breaking the cycles of marginalization of fervent, creative, and resilient youth once termed "at risk."

Immigrant latino youth in general and the case study of Tenoch in particular shows that a direct application of present clinical practices are not enough to provide long-term healing and decolonizing attitudes to survive the academic needs of a border-gender communities. Regular, on-going therapy focused on anti-oppressive practices coupled with Aboriginal healing techniques has proved to be a valid, reliable, and consistent method to increase this vulnerable population's wellbeing without further marginalization. A practitioner might conclude that a mixed model is more affirmative of individual process of personhood while still connected to one's roots and communities of origin. The implication of practice is that a clinician needs to also engage in advocacy, support, and profound transformations in order to unmask both inner and outer colonized mind traps.
\end{abstract}

Keywords: transgender, youth, advocacy, marginalization, colonization, oppression.

\section{Introduction}

\section{From the non-traditional youth to the academically successful one}

The completion of any academic program, such as the school preparation for regular entrance into a degree program at a university, could certainly be called a "triumph of tenacity over terror" (Morgan, 1989, 7-18, 27, 43, 45). ${ }^{1}$ On the one hand, being forced into a plethora of weekly interactions as a high school student makes one grow up, get real, and confront one's limits and unresolved issues. On the other hand, an academic program per se does not provide answers.

Corresponding author:

Silvia Tenenbaum

aljamaconsulting@hotmail.com
It will "prove" nothing, "solve" nothing, and reassure no one. That is not its intention. Rather, it is meant to perform the humbler if irritating function of asking questions, sensing connections, and suggesting perspectives. These may validate a

1 Morgan applies this beautiful expression to the completion of any feminist task, such as her own account of researching into both our fascination with and our repulsion towards terrorism in general and specific terrorists in particular (cf. Morgan, 1989, pp. 17-18, 27, 43, 45), 
few non-traditional students, challenge others, and unsettle some (Morgan, 1989, p.15). How do people really become effective students within the existing system? I believe the key resides in a clear relationship between the student and his/her spiritual needs, which then, and only then, could be projected into the Otherness of academia. Furthermore, the clarity and consistency of the communication (through body, language, and energy) and a willingness to be (or become) a life-long learner might be considered the foundations of such psycho-spiritual encounters.

This paper focuses on such explorations as they relate to the potential of the profound transformation to be propitiated at the end of this unique training for life. Although designed as an assignment, to an external evaluator, the Ministry of Education \& Training in Ontario in general and Ontario universities in particular, this is actually an exploration for oneself, and it basically entertains all possible meanings that the personal growth of the therapist is having in those students' lives. Assignments are always for ourselves, on either side of the counselling session, if we really want to empower and heal both participants.

\section{Method}

\section{Participants: 4 participants between 10-16 years of age, home schooled at first}

Tenoch and his cousin Amalia are part of a visible sexual minority. Tenoch identifies as a "masculine girl, mostly non-gender, female bodied person" (his own definition, as of 2011), while Amalia identifies as queer. Both were home-schooled together by three loving and artistically inclined parents who made sure that the curriculum was pertinent, reliable, and multifaceted. When two more youth also with partial Aboriginal roots-self-identifying as gay and trans-man, respectively-engaged in a formal group study, I was invited to provide ongoing counselling to them. This paper presents the results of the encounters, which lasted six years. Identifiable details have been altered to protect the participants, because after Immigration Canada denied their refugee claims, they all became part of the growing hidden reality of undocumented new Canadians.

\section{Tenoch's own characteristics and original idea as an incoming student: From cycles of shame and trauma to a healing journey}

Tenoch has always been the leader of the group. Tenoch's family is of Mexican Aboriginal ancestry. Tenoch lived in the USA during his first eight years. The family lived undocumented there, and one day, as they told me in personal communication, they had to pack all their belongings in a car and just drive and drive until they reached Canada. In Canada, Tenoch was assessed as gifted, a fact that was very obvious to me after just a few conversations.

Tenoch was at first unaware of gender fluctuations, because he was never exposed to criticism by his protective family, and his relations outside the group had been limited. At the beginning of our clinical engagements I noticed that his family was constantly pointing out that he was "different" and "with different needs", although such commnents were more of a proto-advocacy style than a form of criticism. In fact, they were loving and isolated parents with little knowledge on the subject and no community connections. At first I have noticed that his family pointing out that he is different need not have taken the form of criticism though. Tenoch did not attend school in USA given the difficulties to sort the school system out without proper immigration papers. Moreover, proud of his Aboriginal ancestry, he firmly believed that many souls lived 
First Peoples Child \& Family Review, Volume 7, Number 2, 2013

within him. He was not concerned at all with his different presentations, because he thought the Spirit manifested particularly according to the needs. That all changed once he became exposed to "regular, normal kids," as one teacher put it to him as a newcomer to Toronto. After a semester of daily bullying, Tenoch presented all the characteristics related to a DSM-IV diagnosis that he did not provide permission to mention. The family never accepted that diagnosis, and they took him out of that school and decided to home-school him.

\section{Procedure}

I had the privilege of working with these 4 youths and their families for 6 years, from when all four of them were 11 and 12 until they were 17 and 18 years old. The case study used narrative therapy. Narrative therapy is based on the concept of clients re-authoring their life story. How does narrative therapy work for potential university students coming from a different background and life's four directions? Evidently, our conceptualization, interpretation, and, therefore, understanding of our own life's events change over time, which is a typical aspect of human development. University professors in general, and Transitional Year Program (TYP) instructors in particular, are not well equipped to deal with such incoming students because they themselves are coming from a privileged position in society, whether they publicly or even privately acknowledge this or not. Shame is a common topic for underprivileged students, who may be found in an inner-city high school and even on some college campuses. As it has been put out, for some individuals, their life stories tell of the event of paying respect to a past or present abuser (Knockwood, 2001, p. 142), so their relation to figures of authority can be problematic. To "make room" for ourselves as helpers/healers of others could be seen as a sort of "natural" consequence of having engaged in our own healing. As part of the foundation of the sacred, "engraved within the soul of every person are links to those who have come before us. Our ancestors are the source of our collective narratives, visions and fears. They may also hold the key to understanding our personal struggles. For some people, dealing with their ancestry involves confronting war trauma, alcoholism, madness or violence; for others it is about coming to terms with the choices their predecessors made" (Volkas \& Pendzik, 2012). ${ }^{2}$

Tenoch certainly wanted to heal from past experiences. After having two years of regular hybrid clinical engagements with the group, I learned by chance of a doctor-shaman from Uruguay who was coming to visit a friend of mine in Toronto. I approached him for personal healing, and decided to incorporate some of his Aboriginal techniques in my work with this youth's ancestors. I found that incorporating these techniques provided a richer framework; a calmer understanding of deep-seated emotions, such as historical trauma; and a way to start conversing about unspoken truths. Tenoch then decided to become a student of the shaman to further work on his gender aspects from Aboriginal ways of knowing. The group acknowledged that actual education was irrelevant to their needs as gender-variant youth and also as members of the undocumented community in Toronto, because they need extensive support and community resources based on trust, honour, and respect, which are core values of indigenous ways of relating to each other, nature, community, and family. These four youths had made many attempts at the formal and established educational system. Based on their experience, they rejected the boredom, punitiveness, and irony of being subject to providing the negative expectations of an oppressive self-fulfilment prophecy. Their alternative has been home-schooling and creating

\footnotetext{
2 Taken from the promotional text for the workshop Restoring the Bonds with Our Ancestors through Drama Therapy and Creative Ritual, organized by The International Institute of Applied and Therapeutic Theatre \& Healing Wounds of History, to be conducted by Armando Volkas and Susana Pendzik, August 2-5, 2012, in Oakland, California.
} 
their own community, however small, as an environment of encouragement. To prevent both overt and covert forms of discrimination, the institutionalization of discrimination to marked and unmarked bodies, we, including myself as a clinician, some school authorities, their families and allies advocated for the freedom to generate new curriculum that was both relevant and pertinent. We promoted a newly formed community.

As Chandler and Lalonde (1998) have proven, the political has implications for individual wellness, via cultural continuity. In this case, sexual minorities are also inscribed in specific subcultures within many other ways of being in the world. The more cultural continuity there is, the more solid the mental health of its participants will be (Chandler \& Lalonde, 1998, p. 4).

I agree with Herman that for certain individuals, the "existential task is formidable" (Herman, 1992, p. 101). Nevertheless, "being ready isn't sufficient to produce the mutation" (Taylor, 1989, p. 315). Different students need more ongoing psychosocial support, and a former girl who now presents as a boy needs support that would increase the visibility of a positive role model. In my personal case, it took many years of exploration (and definite answering) of a simple yet rather elegant Biblical question: ${ }^{3}$ Am I my brother's keeper? Yes, I am indeed. In the first half of my life, in Uruguay, it took a political turn; in this second half, in Canada, it is taking a more psycho-social angle. The personal is not only political, it is also ecological, psychological, and spiritual, ${ }^{4}$ to name but a few interconnections. To put it succinctly, academia could theoretically propitiate people's change through a spiritual adjustment to life's circumstances. The process of becoming an adequate teacher at any level is a lifelong path of awakening, attention, surrender, and commitment. It is about a contentment dependent on inner transformation.

\section{Otherness of non-traditional students vis-à-vis the otherness of privileged teachers}

Duran self-defined his work in elegant terms, as an "alchemical amalgamation of Western theory and traditional Aboriginal theory and practice" (Duran, 2006, p. 1). The project involving Tenoch provides a Mexican example situated in Toronto of the otherness of non-traditional students vis-à-vis the otherness of privileged teachers, with all its political nuances, as it was not easy to locate an elder for consultation at first, and a shaman for healing work after. Tenoch himself co-formulated his needs and requested support.

In the case of sexual minority youth being bullied, the members of the group acknowledged that an effective intervention cannot be "cook-booked" for an individual or a community (Duran,

3 Jung explores this beautiful aspect of solidarity in humankind in his so controversial last book, Answer to Job. This book, finally written in 1958 after a life of self-doubt of its author, is mainly concerned with the controversial and frankly heretic nature of such topics as the inconsistency of an anger-seeking God (Jung, 1958/2002, p. 33) and the envy of God towards the superiority of humankind that overpowers him (Jung, 1958/2002, p. 21), among others. In it, the "burning" question (to use a Jungian common term) poses several dilemmas that merit one's definition towards Otherness as an inclusive/exclusive category to be used in the therapeutic encounter. For instance, I helped some of my patients to move from perfection (a more masculine desideratum) to completeness as a feminine person (Jung, 1958/2002, p. 33), to their satisfaction.

4 One of the most fascinating conversations I had this year in relation to the "helping process" at a spiritual level was with Stephen Jenkinson, the director of the Psycho-Spiritual Program at the Temmy Latner Centre for Palliative Care at Mount Sinai Hospital in Toronto. This is the place that I am considering as my doctoral placement, if the day arrives. Due to the urgency of his "counselling" sessions or last rites conversations, he just focuses on a brief and intense spiritual cleansing, to give peace of mind at least in the last days of a person's life. He is not afraid of touching subjects in ways that nobody else would, and that is remarkable in itself, not to mention brave, such as a spiritual meaning of money in one' s life. His background in both social work (M.S.W. from the University of Toronto) and divinity (M.Div. from Oxford University), as well his eclectic life as a sculptor, give him a peculiar outlook at suffering and the creative possibilities it involves. 
First Peoples Child \& Family Review, Volume 7, Number 2, 2013

2006, p. 117), so collaboration and creativity was paramount to their own success. Tenoch and the other three members of the group were finally able to start a different career path under very difficult circumstances (advocating with the college registrar's office, completing bursary applications because they could not receive OSAP given their immigration status). The colonizing mind is always operating, so it was necessary for them to disarticulate historical mechanisms of self-hatred and debasing self-esteem in order to work to generate a robust inner self and a deep connection to one's ancestry, and in turn to better manage the daily encounters of still-prevalent imperial domination of so-called majorities over minorities. Tenoch was able to create a strategy and a healthy management of energies when dealing with the school system. Some teachers were less thrilled than others with him in the classroom, but he did succeed, and, more importantly, he did that on his own terms, partly because he was now ready to have realistic expectations of educators, the curriculum, and his own empowerment practices. Nevertheless, real-life teachers were a constant source of disappointment. As Amalia once said, "I had to fight enough with myself to succeed, but that was nothing compared to the daily fight to have a voice in school." If given the opportunity in a pedagogically conducive environment, those students could teach teachers a lotto everybody's benefit. They need to tell their story, and the school system needs to hear it.

If teachers accepted these students' otherness instead of trying to effectuate a complacent accommodation into the status quo, they could integrate the otherness of the students and from there work on a common ground, where fluidity is the norm and where appreciation of strength and resiliency marks the rhythm of the courses. In my personal experience as a former outof-the-box high school drop-out and, a decade later, as a new refugee in Toronto and a TYP student (1989-1990), I have observed that non-traditional students' fully developed sense of intuition - that wonderfully arcane form of knowledge-helps them create something new, full of hope, resisting the blandishments of those self-serving and flattering world views that hide the austere reality of the human condition in a disenchanted society. I sensed that my ultimate allegiance was there, against those who decry very traumatized populations or who look at them as a pusillanimous second best. I saw myself deeply committed to building over time a web of relationships that gives fullness and meaning to human survivorship. Although I was careful not to impose my personal agenda onto my (already vulnerable) classmates, I realized my direction was already set. Thus, my absolute questions always frame my relative ones. That still resonates when dealing with Tenoch and the others, a very humble project that started with one individual and at the present time involves more than two hundred.

\section{Discussion}

\section{Tenoch in all its gender presentations: Alpha and Omega of development?}

The gender spectrum is a theatre of sorts, a theatre of ever-changing identity presentations. My work with Tenoch and his family proved that healing from sexual violence against gender non-conforming youth like Tenoch is always possible in freedom and creativity. This is also an experiential work about three specific lives - the three loving parents of Tenoch and Amalia-that merged into seeking justice for intersectionality of trans-communities, providing an emotional compass to those who care about sexual and cultural diversity in all its splendour. These parental figures overcame the immigration maze to locate a compassionate therapist, an advocate, two school principals acting together with two brave politicians, and several community members, to help create community for themselves and their loved ones. The therapist needs to be the main advocate and activist, a task not usually recognized as such. 


\section{Result of the project: A never-ending process.}

My clinical engagement, with its overarching principle of a de-colonizing approach, represents a living demystification of several stereotypes that need to be disarticulated in order to grasp the essence of gender-variant individuality. A direct application of Duran's new yet arcane dictum showed that a simplistic, binary view will not be enough to understand trans-women's experiences towards intergenerational sexual violence and their resolution. As a complex yet very approachable individual topic for a healing journey, gender-variant youth like Tenoch embody change and permanence, and that fluidity will definitely enrich any academic and clinical environment, especially one conducive to social change and its appraisal. I have used this family's ethnographic accounts as methodology, coupled with Duran's wise theoretical views, but because these participants are former asylum-seekers living in diaspora, I still needed to travel culturally to interview the doctor-shaman in the countryside of Uruguay, an experience that certainly helped me become a healer myself in and out of that process.

\section{What does it take to create community for trans-kids living in diaspora?}

I was helped in my interactions with Tenoch and the others by my various living experiences, both in Latin America (Brazil, Uruguay, and Cuba) and in Canada (Montreal and Toronto); by my family's origin, which has Jewish roots in a Muslim country (Lebanon); by growing up Jewish in a Catholic environment (Uruguay); by being racially white in a Latin-American continent, but a Latina in an Anglo-Saxon one. All these categories within my life contribute to the relativization of all definitions, and the profound contextualization of individual notions. By having oscillated between multiple paradigms, I am now proposing a better integration of theory into practice, and a reduction of its academic and clinical gap: We have to provide incoming counsellors with a secure base of healing techniques, display an openness towards our clients' indigenous background, and invite ancestral work as part of the profound change needed. As the unconventional educator Leo Buscaglia once said, "awareness is terminable, but knowledge is eternal"-something that children intuitively know (Buscaglia, 1982, p. 93). It has been my experience working with Tenoch that he already knew all he needed to know about himself, but work still had to be done around the awareness to create a strategy and to manifest his self into this specific context.

Although I consider myself a very integrated Canadian, I self-identify as a Third World country woman because my feminist views coincide with the needs of that region and resist the blandishments that hide the austere reality of the human condition in a disenchanted world. However, my dual viewpoint is manifested in any intervention of mine, for I have lived experience of many of the issues my research subjects may also present with. Because I certainly don't share patriarchal views of women as a pusillanimous second best, that position permeates empowerment practices I live by. And I think that precisely those multiple living experiences allowed me to work productively with these youth, as they were seeking a different approach to learning and teaching that the regular school system could not or would not give them.

Tenoch had a penchant for mythical explanations of his present life, as well as ritualistic connections to feelings, sensations, and natural phenomena. Thus, narrative therapy was a natural approach for self-exploration. For instance, I used my graduate studies in literature to interpret ancient myths into the light of modern dilemmas, which in turn might open up another angle of a problem. Similarly, certain elements of Khabbalistic thought, so prevalent in Jungian analysis (my therapeutic choice in my private practice), might help create an atmosphere open 


\section{First Peoples Child \& Family Review, Volume 7, Number 2, 2013}

to the imagination, so needed in time of crisis after a sexual assault. Different experiences can be interpreted according to the viewer, to the enrichment of the therapeutic encounter in its healing outcome. In other words, I engage in the transformation of chaos into a meaningful cosmos within a viable web of multiple and often co-existent social realities. When assessing for a culturally pertinent intervention, we usually don't take Aboriginal roots into consideration, although its articulation into treatment further advances the intensity of the issue, and its articulation into a whole family system both inflected and affected by usually the same issue(s) under various presentation worth a deeper analysis.

\section{Conclusion}

\section{Update about Tenoch and the other members of this project}

This is a real-life story, so there are mixed endings. Tenoch is now working at a trans-friendly community centre in downtown Toronto as a peer counsellor for trans-kids. Amalia still lives at home. She is out of the closet in all aspects of her life, still struggling with a self-definition in both gender presentation and gender orientation, producing art and showing her works in alternative cafés around Queen Street, Toronto's artistic district. The other two participants are still sometimes living on the streets, engaging in self-harming activities from time to time, but producing wonderful graffiti and popular theatre for the anti-psychiatric movement. All four of them are meeting regularly to engage other youth and to disseminate their stories, as all of them have finally recaptured their ancestors within.

Their lives do not seem now to be overburdened, although they are still complicated affairs. But they have chosen life, poetry, photography, sketches, and theatre to voice their existences.

\section{References}

Buscaglia, L. F. (1982). Living, loving and learning. New York, NY: Fawcett Columbine.

Chandler, M. J., \& Lalonde, C. (1998). Cultural continuity as a hedge as against suicide in Canada's First Nations. Transcultural Psychiatry, 35, 191-219.

Duran, E. (2006). Healing the soul wound: Counseling with American Indians and other Native Peoples. New York, NY: Teacher's College Press.

Herman, J. (1992). Trauma and recovery: The aftermath of violence-from domestic abuse to political terror. New York, NY: Basic/Perseus.

Jenkinson, S. (2002). Money and the soul's desires: A mediation. Toronto, ON: Stoddart.

Jung, C. G. (1958/2002). Answer to Job. Toronto, ON: Inner City Books.

Knockwood, I. (2001). Out of the depths: The experience of Mi'kmaw children at the Indian Residential School at Shubenacadie. Black Point, NS: Roseway.

Morgan, R. (1989). The demon lover: On the sexuality of terrorism. New York, NY: Norton.

Taylor, C. (1989). Sources of the self: The making of modern identity. Cambridge, MA: Harvard University Press.

Volkas, A. \& Pendzik, S. (2012). Institute of Applied and Therapeutic Theatre \& Healing the Wounds of History. Oakland, CA. 